\title{
Chapter 6 \\ What Have We Learned About Gender Differences in ICT?
}

\begin{abstract}
Gender differences among school students in the use of information and communications technologies (ICT) and their ICT literacy have been of interest over a number of years because ICT has become so central to education, work, and life in modern societies. This report presents results from detailed analyses of differences in computer and information literacy (CIL) across 14 countries. It finds that even though female students demonstrated higher levels of CIL than did male students there are some differences in specific aspects of CIL. Female students performed relatively better on tasks that involved communication, design, and creativity, and male students generally performed relatively better on more technical tasks. Moreover, male students were more confident than female students in their ability to perform specialized ICT tasks. Even though there were some gender differences in patterns of use of ICT, these differences did not appear to be related to differences in CIL. In addition, there were no appreciable differences between female and male teachers in their pedagogical use of ICT or in their dispositions towards its use.
\end{abstract}

Keywords Computer and information literacy (CIL) • Gender differences • Information and communications technologies (ICT) - International Computer and Information Literacy Study (ICILS) • International large-scale assessments

\subsection{Introduction}

There was once a pervasive belief that male students had an advantage over female students in both access to and proficiency in the use of information and communication technology (ICT). This report challenges those beliefs and suggests that a more nuanced interpretation is required. We analyzed data collected from both teachers and students from the IEA International Computer and Information Literacy Study (ICILS) conducted in 2013 (Fraillon et al. 2014) to determine the nature and extent of gender differences in computer use and beliefs about computers in schools across 14 countries. 


\subsection{Gendered Differences in CIL}

We found that, on average, female students achieved higher scores for computer and information literacy (CIL) than male students. Although this difference was small in magnitude (about one-fifth of a standard deviation, on average) it was statistically significant in 12 of the 14 countries considered in ICILS 2013. However, differential item functioning (DIF) analyses of the data indicated that female students generally performed relatively better on tasks that involved communication, design, and creativity, and that male students generally performed relatively better on more technical tasks. Punter et al. (2017) reported similar results in a separate exploration of male and female student performance in ICILS 2013.

Examination of the relative ICT self-efficacy ratings (or confidence in using ICT) of female and male students regarding different aspects of ICT provides additional insight into this pattern of female superiority in CIL. Within the ICILS measure of ICT self-efficacy, it is possible to identify aspects that reflect general skills and aspects that reflect specialized skills. At the general levels of ICT self-efficacy, there were few differences between female and male students, however, male students generally assessed their ability to perform specialized ICT tasks significantly higher on the self-efficacy scale than did their female peers. Moreover, general ICT selfefficacy is more closely associated with CIL than specialized ICT self-efficacy for both female and male students in most countries.

The use of ICT applications that were related to information management and communication does not appear to be linked to increased competence in specialized and technical aspects of ICT, but is associated with competence in general aspects of ICT use. We therefore suggest that a construct such as computational thinking may produce different patterns of gender differences to those observed for CIL.

\subsection{Response to and Use of ICT}

This report also investigated differences between female and male students' affective responses to and use of ICT. Male students reported slightly higher levels of interest in and enjoyment of ICT than their female peers in 13 of 14 countries. In addition, interest and enjoyment appeared to be more strongly related to CIL among male students than among female students. Hence, the higher levels of CIL achieved by female students do not appear to be driven by interest and enjoyment of the area. Examination of gender differences in patterns of ICT use did not provide any insights into gender differences in CIL. There were few differences between male and female students in their use of productivity applications. Female students reported more frequent use of ICT for social communication in many, but not all, countries. More frequent use of ICT for social communication appeared to be associated with CIL to a small extent in about half of the countries. There was no clear pattern of gender differences in ICT use for exchange of information or in the associations between 
this form of ICT use and CIL. This relationship, however, was generally negative for both female and male students when taking into account the effects of differences in interest and enjoyment, and differences in other types of ICT use. Using ICT for recreation tended to be higher among male students in six of the countries, and was associated with higher CIL for both male and female students. Perhaps, recreational use of ICT reflects a greater familiarity with ICT, or perhaps those who are proficient in CIL are more likely to be everyday users of ICT for recreational purposes. However, this relationship was found in more countries for female students than for male students.

In summary, while there may be some gendered patterns of use of ICT these differences do not appear to be a plausible explanation of the differences in CIL between male and female students in terms of CIL achievement found by ICILS 2013. These findings are consistent with other research on the topic (Punter et al. 2017).

\subsection{Teachers and ICT}

The inescapable conclusion from our analyses of female and male teachers' experience, dispositions toward, and use of ICT is that any differences are small and inconsistent across countries. Female and male teachers in secondary schools do not appear to differ in the extent of their pedagogical use of ICT.

Female teachers, on average, reported slightly more experience in using computers for teaching than male teachers. Female and male teachers did not differ overall in either positive or negative views regarding the use of ICT in education, but, in some countries, female teachers reported slightly more positive views about the use of ICT in education than male teachers. Female and male teachers differed in their confidence (self-efficacy) in using computer technology. On average, male teachers recorded slightly higher ICT self-efficacy scores than female teachers, but this pattern differed among countries.

On average, $70 \%$ of male teachers and $77 \%$ of female teachers said they used ICT to support teaching in the classroom. There were small differences in a few countries in the amount of emphasis placed on teaching ICT-based capabilities to students, but where a difference was observed, it generally indicated that female teachers put greater emphasis on teaching ICT skills to students than male teachers did. For both female and male teachers, greater experience in using ICT in the classroom, higher ICT self-efficacy, and more positive views about using ICT in learning and teaching all contributed toward a stronger emphasis on developing students' ICT skills.

Given the relatively small differences between female and male teachers in their pedagogical use of ICT, it seems unlikely that teacher gender contributes to the observed gender differences in students' CIL performance. We were unable to link teacher characteristics or practices to student CIL, because the student and teacher samples in each school are independent in the ICILS assessments. 
ICILS 2013 was the first major international assessment of ICT literacy in schools, and provided a wealth of information on student achievement in CIL, their attitudes toward and beliefs about ICT, as well as the respective attitudes and beliefs of their teachers. In the five years since the release of that report, the use of ICT has continued to grow at a rapid rate. Computer use has become even more ubiquitous, but has that translated into increased use in schools or affected the level of use by students in their schooling? Has the way in which students use computers at school changed over the past five years? Are there still gender differences in the same areas as in ICILS 2013?

ICILS 2018 (Fraillon et al. 2019) provides a link to ICILS 2013, which will enable researchers to monitor changes over the period from 2013 to 2018 for those countries that participated in both cycles. ICILS 2018 will also report on computational thinking, which can be thought of as the type of thinking used when programming a computer or developing an application for another type of digital device. Computational thinking is being able to recognize aspects of real-world problems that are amenable to computational formulation and develop algorithmic solutions to those problems (Fraillon et al. 2019). This therefore involves conceptualizing problems (through understanding digital systems, formulating problems, and collecting or representing data) and operationalizing solutions (through planning solutions to problems, and developing algorithms and programs). Data from this study will provide an opportunity to reflect on changes for male and female students over this five-year period, and will also provide an opportunity to examine the skills and beliefs of students in these new areas of assessment.

\section{References}

Fraillon, J., Ainley, J., Schulz, W., Friedman, T., \& Gebhardt, E. (2014). Preparing for life in a digital age: The IEA International Computer and Information Literacy Study international report. Cham, Switzerland: Springer. Retrieved from https://www.springer.com/gp/book/9783319142210.

Fraillon, J., Ainley, J., Schulz, W., Duckworth, D., \& Friedman, T. (2019). IEA International Computer and Information Literacy Study 2018 assessment framework. Cham, Switzerland: Springer. Retrieved from https://www.springer.com/gp/book/9783030193881.

Punter, R., Meelissen, M., \& Glas, C. (2017). Gender differences in computer and information literacy: An exploration of the performances of girls and boys in ICILS 2013. European Educational Research Journal, 16(6), 762-780. Retrieved from https://doi.org/10.1177/ 1474904116672468. 
Open Access This chapter is licensed under the terms of the Creative Commons AttributionNonCommercial 4.0 International License (http://creativecommons.org/licenses/by-nc/4.0/), which permits any noncommercial use, sharing, adaptation, distribution and reproduction in any medium or format, as long as you give appropriate credit to the original author(s) and the source, provide a link to the Creative Commons license and indicate if changes were made.

The images or other third party material in this chapter are included in the chapter's Creative Commons license, unless indicated otherwise in a credit line to the material. If material is not included in the chapter's Creative Commons license and your intended use is not permitted by statutory regulation or exceeds the permitted use, you will need to obtain permission directly from the copyright holder.

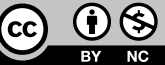

